\title{
Homing of Gyrodactylus salaris and G. derjavini (Monogenea) on different hosts and response post-attachment
}

\author{
Kurt Buchmann, Kenneth K. Madsen and Michael B. Dalgaard
}

Department of Veterinary Microbiology, Section of Fish Diseases, Royal Veterinary and Agricultural University, Stigbøjlen 4, DK-1870 Frederiksberg C., Denmark

Key words: salmonids, Gyrodactylus, host specificity, colonisation, host response

\begin{abstract}
In natural European waters, the congeneric monogeneans Gyrodactylus derjavini Mikailov, 1975 and G. salaris Malmberg, 1957 are primarily found on brown trout Salmo trutta L. and Atlantic salmon Salmo salar L., respectively. Interestingly, rainbow trout, Oncorhynchus mykiss (Walbaum), originating from North America, is as susceptible as brown trout to G. derjavini. However, the mechanisms involved in this host specificity are poorly understood but may include behavioural, mechanical and chemical factors affecting parasite attraction, attachment, feeding, reproduction and host responses. In the present laboratory work, this question has been studied. Detached parasites (either G. derjavini or G. salaris) were offered a choice in small aquaria between fry of rainbow trout, Atlantic salmon and carp Cyprinus carpio L. Within 48 hours more than $90 \%$ of $G$. derjavini colonised rainbow trout and left salmon almost uninfected. Some parasites were found on carp. During the same time span, more than $60 \%$ of $G$. salaris attached to salmon, the rest infected rainbow trout and none were found on carp. Following attachment, the parasites need appropriate stimuli to initiate feeding and reproduction but even such a successful specific colonisation can be followed by a host response. Both humoral and cellular elements have been suggested to participate in these reactions but in the present work it was demonstrated by immunoblotting and immunocytochemistry that no antibodies in host mucus and host plasma bound to any parasite structures or epitopes.
\end{abstract}

Many species within the monogenean genus Gyrodactylus von Nordmann, 1832 are host specific (Bakke et al. 2002) but the basis for this specificity is still insufficiently known (Buchmann and Lindenstrøm 2002). The present comparative study using the congeners Gyrodactylus salaris Malmberg, 1957 and G. derjavini Mikailov, 1975 has been conducted in order to elucidate some of the mechanisms involved. In natural European waters, G. derjavini shows high preference for brown trout Salmo trutta L. (Malmberg 1993, Mo 1993, 1997, Buchmann et al. 2000). Interestingly, the introduced rainbow trout Oncorhynchus mykiss (Walbaum) is also highly susceptible to this parasite both in farms and natural waters (Buchmann and Uldal 1997, Buchmann et al. 2000). G. salaris colonises $S$. salar L. often in high numbers whereas $S$. trutta normally harbour much lower intensities of this gyrodactylid (Mo 1991, 1997, Malmberg 1993, Harris et al. 2000, Dalgaard et al. 2003). Rainbow trout shows varying susceptibility to $G$. salaris but in our experimental system this teleost is considered a less suitable host (Dalgaard et al. 2004). Further, even after successful colonisation of a fish with an appropriate gyrodactylid species, the host may mount a response some weeks post-infection (Lester 1972, Lester and Adams 1974, Scott and Robinson 1984, Cone and Cusack 1988, Richards and Chubb 1996, Buchmann and Uldal 1997, Lindenstrøm and Buchmann 2000, Bakke et al. 2002, Dalgaard et al. 2003). However, the molecular interactions involved in this event need further elucidation. To elucidate the factors con- trolling host preferences and responses, we have established two parasite-host systems in the laboratory, $G$. derjavini on rainbow trout and $G$. salaris on salmon. Here we report on controlled host colonisation experiments. Further, the interactions between host mucus and plasma and parasite following parasite attachment has been elucidated by the use of immunological techniques.

\section{MATERIALS AND METHODS}

Fish. Rainbow trout and salmon used in the experiments were hatched and reared at the Bornholm salmon hatchery (Nexø, Bornholm) in a recirculated system without pathogens. Eggs of Atlantic salmon Salmo salar (from both the East Atlantic Scottish river Conon stock and the Baltic Lule river stock) and rainbow trout Oncorhynchus mykiss (from the Danish trout farm Faarup Mølle in Jutland) were brought to the hatchery. Following disinfection in iodophore (Actomar K30), the eggs were incubated in hatching trays and hatched in municipal freshwater at $\mathrm{pH} 7.8$ and at a temperature of $7^{\circ} \mathrm{C}$. Fish were fed commercial pelleted feed (BioMar A/S, Denmark) at $10^{\circ} \mathrm{C}$ during the pre-experimental period. Carp (Cyprinus carpio) fry was obtained from a laboratory stock (Wageningen University, The Netherlands).

Parasites. Gyrodactylus derjavini Mikailov, 1975 was isolated from a Danish freshwater trout farm and kept in the laboratory (100-200-litre aquaria with internal Eheim biofilters) on susceptible rainbow trout before experimentation.

This paper was presented at the 6th International Symposium on Fish Parasites in Bloemfontein, South Africa, 22-26 September 2003. 
Gyrodactylus salaris Malmberg, 1957 was imported on live salmon from Laerdalselva in Norway and kept in our isolated laboratory on susceptible Atlantic salmon (Conon stock) before experimentation.

Colonisation experiments. Small aquaria (17 litre total volume with 3 litre water) were added between 20 and 30 parasite specimens in a Petri dish (either G. salaris or G. derjavini, 12 replicates for each species) at a temperature of $12^{\circ} \mathrm{C}$. The parasites had been isolated by placing a heavily infected fin in a Petri dish with water, whereupon parasites left the fin and attached to the Petri dish bottom. This Petri dish was then placed in the aquarium. Subsequently one rainbow trout, one salmon (Conon stock) and one carp were added (body length $5-6 \mathrm{~cm})$ to the aquarium with parasites. These fishes were anaesthetized at 1, 2, 4, 8, 24 and $48 \mathrm{~h}$ post-exposure and examined for infection under the dissection microscope $(7-40 \times$ magnification)

Blood and mucus sampling. Samples were taken from both East Atlantic Conon salmon and Baltic Lule salmon because these two stocks have shown different susceptibility to G. salaris infection (Dalgaard et al. 2003). These fish had body length $10-12 \mathrm{~cm}$ and had been infected with $G$. salaris for 6 weeks. Uninfected control fish from the same stocks were similarly sampled. They were anaesthetized (MS 222 $50 \mathrm{mg} / \mathrm{l}$, Sigma-Aldrich, Denmark) and blood samples were taken by caudal vein puncture using heparinized syringes (10 fish per group). Blood was centrifuged and plasma recovered and stored at $-20^{\circ} \mathrm{C}$ until use. Mucus was taken from the same fish by rubbing the flanks with a plastic sheet and transferring the recovered mucus to cryotubes and stored at $-20^{\circ} \mathrm{C}$ until use.

Western blot. Gyrodactylus salaris specimens were collected from heavily infected Conon salmon under the microscope and transferred to Eppendorf tubes and prepared for reduced and non-reduced SDS-PAGE (sodium-dodecyl-sulphate-polyacrylamide-gel-electrophoresis) in sample buffer and run in $10 \%$ polyacrylamide (Novex Thermo Flow system, Invitrogen) with MOPS-SDS running buffer (3-(N-morpholino) propane sulfonic acid). Subsequently, the gel was silverstained (SilverXpress, Invitrogen) or protein bands electroblotted onto nitrocellulose (X-cell system, Invitrogen). The membrane was cut into strips each representing a lane with parasite proteins. These were blocked in blocking buffer (phosphate buffered saline, PBS, pH 7.2 with $1 \%$ skimmed milk) for 20 min. Subsequently, the strips were incubated at room temperature with plasma (diluted 1:40 in dilution buffer, $0.01 \%$ skimmed milk in PBS) from either infected or noninfected salmon (both stocks) for $1 \mathrm{~h}$, rinsed $3 \times 5$ min with washing buffer (PBS with $0.05 \%$ Tween 20), incubated with rabbit anti-salmon Ig (Buchmann and Pedersen 1994) for $1 \mathrm{~h}$ (1:1000 dilution), rinsed again and finally incubated with peroxidase-conjugated goat anti-rabbit Ig (Sigma A-0545). After the final wash, antibody binding was visualised by adding substrate DAB (3,3'-diamino-benzidine tetra-hydrochloride, Kem-En-Tec Diagnostics A/S) with hydrogen peroxide. Positive protein bands stain dark-brown.

Immunohistochemistry. Parasites (G. salaris) recovered from Conon salmon were formalin-fixed ( $4 \%$ formaldehyde in PBS, pH 7.2), blocked in blocking buffer, rinsed and incubated in plasma (diluted 1:10) or in mucus (diluted 1:3) recovered from either Conon or Lule salmon. Following $1 \mathrm{~h}$ incubation, the parasites were treated as described above for Western blotting to visualise host antibody binding directly to structures on G. salaris. Reactions were studied in the compound light microscope on parasites mounted in glycerinegelatine.

Statistics. The numbers of parasites attached to different fish species were compared using the Chi-square test. A probability level of 5\% was used.

\section{RESULTS}

\section{Fish behaviour}

The three fish species differed slightly with respect to behaviour in the experimental aquaria. Thus, carp fry were in close contact with the bottom (and the parasites) most of the time whereas salmon and rainbow trout were exhibiting bursts of swimming between their resting periods in contact with the substrate. However, all fish were observed to contact the parasite-containing substrate.

\section{Host selection}

Both species of Gyrodactylus attached readily to fish. Thus, more than $80 \%$ of the parasites left the substrate and infected the fish, which means that of 30 detached parasites more than 24 found a host. Due to the different number of parasites in the different tanks, colonisation success is shown in percentage. Gyrodactylus derjavini attached preferentially to rainbow trout when offered the choice between salmon, trout and carp (Fig. 1). This was seen already after $1 \mathrm{~h}$ but was further emphasised during the following $48 \mathrm{~h}$ where $91 \%$ of the parasites were harboured by the rainbow trout, $7 \%$ by carp and only $1 \%$ by salmon. In contrast, G. salaris colonised preferentially salmon, showed lower interest for rainbow trout and rejected carp (Fig. 2). Thus, 66\% of $G$. salaris were found on salmon, $34 \%$ on rainbow and none on carp at $48 \mathrm{~h}$. It was noted that $G$. salaris showed higher preference for rainbow trout than $G$. derjavini showed for salmon. Generally, $85-95 \%$ of the parasites attached to the experimental fishes.

\section{Antibody binding}

SDS-PAGE revealed that $G$. salaris proteins are separated into a number of peptides with molecular weight ranging from less than $14 \mathrm{kDa}$ to more than 96 $\mathrm{kDa}$. No antibody binding was seen during the Western blot procedure. Likewise, the immunocytochemical studies on whole worms showed no antibody reactivity of plasma and mucus to parasite epitopes.

\section{DISCUSSION}

In our experimental parasite-host systems it has been demonstrated that Gyrodactylus derjavini has a clear ability to propagate on brown trout and rainbow trout but not on salmon (Buchmann and Uldal 1997) and that $G$. salaris readily multiplies on salmon but not on rainbow trout (Dalgaard et al. 2004). In other situations and locations $G$. salaris may show higher affinity for rain- 


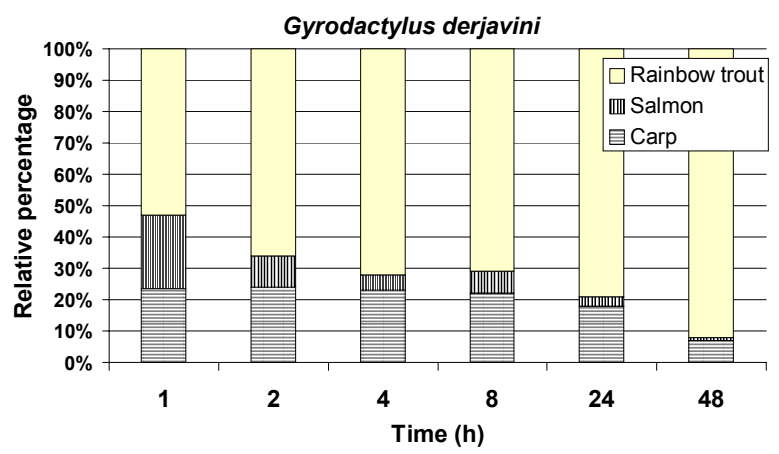

Fig. 1. Relative percentage of attached Gyrodactylus derjavini on particular hosts in relation to all attached parasites (100\%) during 48-h exposure to carp, salmon and rainbow trout. Significant differences at all sampling points $(\mathrm{p}<0.05)$.

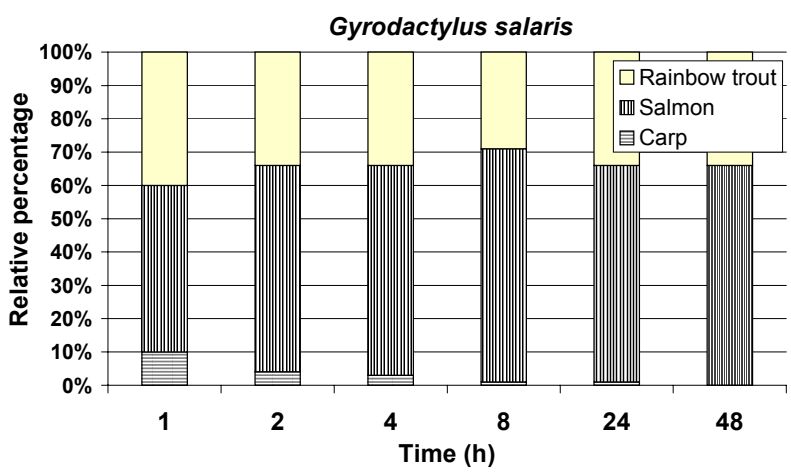

Fig. 2. Relative percentage of attached Gyrodactylus salaris on particular hosts in relation to all attached parasites (100\%) during 48-h exposure to carp, salmon and rainbow trout. Significant differences at all sampling points $(\mathrm{p}<0.05)$.

bow trout (Malmberg 1993). In our laboratory systems the appropriate parasite will attach to and subsequently propagate for a period on the fish. Although both parasites will to a certain extent attach to the inappropriate host, if this is the only choice (Buchmann and Uldal 1997), it has been demonstrated in this work that the parasites preferentially attach to the appropriate host if given a choice. It is noteworthy that the affinity for carp differed between $G$. derjavini and $G$. salaris. Where carp was tolerated by the former parasite for up to $48 \mathrm{~h}$, this fish was rejected by the latter species already $8 \mathrm{~h}$ post-attachment. Likewise, where $G$. derjavini rejected salmon within $48 \mathrm{~h}$, the congener $G$. salaris remained on rainbow trout in the same period. This difference may have important implications for host-switching mechanisms (see Bakke et al. 2002). Thus, G. derjavini may switch from trout to carp whereas it is not particular likely that $G$. salaris establish populations on this cyprinid. Both host behaviour, chemical substances (Kearn 1967, Buchmann and Lindenstrøm 2002), mucus pH (Hirazawa et al. 2003) and mechanical (water currents) factors can be suggested to influence such host choices by monogeneans.
In this investigation the fish species with highest contact with parasites on the substrate (the carp) showed the lowest infection, which will suggest that chemical factors play a role and that water currents are of less importance. Gyrodactylids possess tegumental sensory organs (Lyons 1969, Watson and Rohde 1994) which may direct an attaching response through the welldeveloped neuromuscular system (Halton et al. 1998). It has been speculated that chemoattractants from the host may direct a free-swimming monogenean parasite larva towards the host (Kearn 1967) which also has been suggested for non-swimming monogeneans such as gyrodactylids by Buchmann and Lindenstrøm (2002). The exact chemical nature of such attractants is not known but lectin-carbohydrate interactions between fish and monogenean may be involved in attachment of parasite stages on the host (Yoshinaga et al. 2000, 2002, Buchmann 2001). This is in accordance with the observation that the most mucous-cell-rich skin regions are the most attractive in the early phase of infection (Buchmann and Bresciani 1998) but this topic should be further investigated.

It has also been described that rainbow trout reacts to $G$. derjavini some weeks post-infection (Buchmann and Uldal 1997, Lindenstrøm and Buchmann 2000). However, no antibody reactivity against this monogenean was detected in infected rainbow trout (Buchmann 1998). Likewise, a few selected strains of the Baltic salmon mount antiparasitic responses to $G$. salaris infection. Thus, the Russian Neva strain (Bakke et al. 1990) and the Swedish Lule strain (Dalgaard et al. 2003) will reduce $G$. salaris infrapopulations within few weeks post-infection. In contrast, Norwegian Lieralva, Scottish Conon and even the Baltic Indalsälv salmon strains do not react (Dalgaard et al. 2003, Bakke et al. 2004).

In the present study, both susceptible Conon salmon and responding Lule salmon were included to detect differences, if any, in antibody responsiveness. Irrespectively of response pattern, no antibody reactivity was found in these fishes, either in mucus or in plasma. A number of workers have shown that antibodies from the host bind to antigens in gill monogeneans (Vladimirov 1971, Buchmann 1993, Bondad-Reantaso et al. 1995, Wang et al. 1997, Mazzanti et al. 1999, Kim et al. 2000, Rubio-Godoy et al. 2003a, b). However, it seems that gyrodactylids infecting the skin and fins of teleosts affect the host differently. Therefore, the basis for the response against gyrodactylids is not likely to be associated with immunoglobulin reactivity. Factors such as complement (Buchmann 1998, Buchmann and Bresciani 1999, Bakke et al. 2000, Harris et al. 2000) have been demonstrated to affect the parasites substantially. If lectins present in fish skin (Buchmann 2001) can activate the complement system following binding to gyrodactylids should be elucidated. The response reaction may be composed of a number of other elements. Recently, it 
has been demonstrated that $G$. derjavini elicits the expression of a number of immune relevant genes in rainbow trout skin (Lindenstrøm et al. 2003, 2004). Thus, the pro-inflammatory cytokine interleukin-1 beta is expressed within a few days post-infection. This molecule may initiate a range of other immune reactions (Lindenstrøm et al. 2003). In accordance with this, it was further shown that expression of genes in skin encoding tumour necrosis factor alpha, transforming growth factor, cyclo-oxygenase and nitric oxide synthetase were found post-infection (Lindenstrøm et al. 2004). Therefore, the host response at least in some systems seems to be associated with a number of factors in an intricate network as suggested previously (Buchmann 1999). The mechanical and chemical stimulation of the epidermis by gyrodactylids elicits the production of cytokines which in turn initiates various responses including mucus secretion (Wells and Cone 1990, Buchmann and Bresciani 1998, Sterud et al. 1998, Dalgaard et al. 2003). Reactive oxygen and nitrogen radicals, lectins and complement factors may subsequently be released whereby reactive leukocytes may be attracted to the site of infection (Buchmann 1999, Lindenstrøm et al. 2004).
In conclusion, the specific attachment and establishment of gyrodactylids to the appropriate fish seems to be mediated by a host factor possibly related to mucous and epithelial cells. However, the same cells appear to be involved in the subsequent host reaction against the parasites. As no antibody reaction was found in the skin or plasma and taking into consideration that complement, lectins, iNOS, COX2, Il-1 and TNF are activated by the gyrodactylid, it is appropriate to suggest that a number of immune mechanisms contribute to the antigyrodactylid response. This emphasises the dynamic activity and importance of fish epidermis for parasite-host interactions.

Acknowledgements. This work was supported by the EUgrant QLRT-2000-01631 and the research network SCOFDA (Sustainable Control of Fish Diseases in Aquaculture). The authors are indebted to Dr. Tor Atle Mo at the National Veterinary Institute, Norway, for supplying the G. salaris strain. Dr. Geert Wigertjes from Wageningen Agricultural University is acknowledged for providing carp fry. The pre-experimental management of fish in the hatchery by John Haakonson, Claus Jespersen and Julia Lynne Overton is gratefully acknowledged.

\section{REFERENCES}

BAKKE T.A., JANSEN P.A., HANSEN L.P. 1990: Differences in host resistance of Atlantic salmon, Salmo salar L., stocks to the monogenean Gyrodactylus salaris Malmberg, 1957. J. Fish Biol. 37: 577-587.

BAKKE T.A., SOLENG A., LUNDE H., HARRIS P.D. 2000: Resistance mechanisms in Salmo salar stocks infected with Gyrodactylus salaris. Acta Parasitol. 45: 272.

BAKKE T.A., HARRIS P.D., CABLE J. 2002: Host specificity dynamics: observations on gyrodactylid monogeneans. Int. J. Parasitol. 32: 281-308.

BAKKE T.A., HARRIS P.D., HANSEN H., CABLE J., HANSEN L.P. 2004: Susceptibility of Baltic and East Atlantic salmon Salmo salar stocks to Gyrodactylus salaris (Monogenea). Dis. Aquat. Org. 58: 171-177.

BONDAD-REANTASO M.G., OGAWA K., YOSHINAGA T., WAKABAYASHI H. 1995: Acquired protection against Neobenedenia girellae in Japanese flounder. Fish Pathol. 30: 233-238.

BUCHMANN K. 1993: A note on the humoral immune response of infected Anguilla anguilla against the gill monogenean Pseudodactylogyrus bini. Fish Shellfish Immunol. 3: 397-399.

BUCHMANN K. 1998: Binding and lethal effect of complement from Oncorhynchus mykiss on Gyrodactylus derjavini (Platyhelminthes: Monogenea). Dis. Aquat. Org. 32: 195-200.

BUCHMANN K. 1999: Immune mechanisms in fish skin against monogeneans - a model. Folia Parasitol. 46: 1-9.

BUCHMANN K. 2001: Lectins in fish skin: do they play a role in monogenean-fish host interactions? J. Helminthol. 75: $227-232$.
BUCHMANN K., BRESCIANI J. 1998: Microenvironment of Gyrodactylus derjavini on rainbow trout Oncorhynchus mykiss: association between mucous cell density in skin and site selection. Parasitol. Res. 84: 17-24.

BUCHMANN K., BRESCIANI J. 1999: Rainbow trout leukocyte activity: influence on the ectoparasitic monogenean Gyrodactylus derjavini. Dis. Aquat. Org. 35: 13-22.

BUCHMANN K., LINDENSTRØM T. 2002: Interactions between monogenean parasites and their fish hosts. Int. J. Parasitol. 32: 309-319.

BUCHMANN K., LINDENSTRØM T., NIELSEN M.E., BRESCIANI J. 2000: Diagnosis and occurrence of ectoparasite infections (Gyrodactylus spp.) in Danish salmonids. Dansk Vet. Tidsskr. 83: 15-19.

BUCHMANN K., PEDERSEN K. 1994: A study on teleost phylogeny using specific antisera. J. Fish Biol. 45: 901903.

BUCHMANN K., ULDAL A. 1997: Gyrodactylus derjavini infections in four salmonids: comparative host susceptibility and site selection of parasites. Dis. Aquat. Org. 28: 201-209.

CONE D.K., CUSACK R. 1988: A study of Gyrodactylus colemanensis Mizelle and Kritsky, 1967 and Gyrodactylus salmonis (Yin and Sproston, 1948) (Monogenea) parasitizing captive salmonids in Nova Scotia. Can. J. Zool. 66: 409-415.

DALGAARD M.B., LARSEN T.B., JORNDRUP S., BUCHMANN K. 2004: Different resistance status of Atlantic salmon strains and rainbow trout to Gyrodactylus salaris infections. J. Aquat. Anim. Health (In press.) 
DALGAARD M.B., NIELSEN C.V., BUCHMANN K. 2003 Comparative susceptibility of two races of Salmo salar (Baltic Lule river and Atlantic Conon river strains) to infection with Gyrodactylus salaris. Dis. Aquat. Org. 53: 173-176.

HALTON D.W., MAULE A.G., MAIR G.R., SHAW C. 1998: Monogenean neuromusculature: some structural and functional correlates. Int. J. Parasitol. 28: 1609-1623.

HARRIS P.D., SOLENG A., BAKKE T.A. 1998: Killing of Gyrodactylus salaris (Platyhelminthes, Monogenea) mediated by host complement. Parasitology 117: 137-143.

HARRIS P.D., SOLENG A., BAKKE T.A. 2000: Increased susceptibility of salmonids to the monogenean Gyrodactylus salaris following administration of hydrocortisone acetate. Parasitology 120: 57-64.

HIRAZAWA N., OSHIMA S., MITSUBOSHI T., YAMASHITA S. 2003: Mucus pH of the tiger puffer Takifugu rubripes is an important factor for host identification by the monogenean Heterobothrium okamotoi. Parasitology 127: $225-230$.

KEARN G. 1967: Experiments on host-finding and hostspecificity in the monogenean skin parasite Entobdella soleae. Parasitology 57: 585-605.

KIM K.H., HWANG Y.J., CHO J.B., PARK S.I. 2000: Immunization of cultured rockfish Sebastes schlegeli against Microcotyle sebastis (Monogenea). Dis. Aquat. Org. 40: 29-32.

LESTER R.J.G. 1972: Attachment of Gyrodactylus to Gasterosteus and host response. J. Parasitol. 58: 717-722.

LESTER R.J.G., ADAMS J.R. 1974: A simple model of a Gyrodactylus population. Int. J. Parasitol. 4: 497-506.

LINDENSTRØM T., BUCHMANN K. 2000: Acquired resistance in rainbow trout against Gyrodactylus derjavini. J. Helminthol. 74: 155-160.

LINDENSTRØM T., BUCHMANN K., SECOMBES C.J. 2003: Gyrodactylus derjavini infection elicits IL-1 beta expression in rainbow trout skin. Fish Shellfish Immunol. 15: 107-115.

LINDENSTRØM T., SECOMBES C.J., BUCHMANN K. 2004: Expression of immune response genes in rainbow trout skin induced by Gyrodactylus derjavini infections. Vet. Immunol. Immunopathol. 97: 137-148.

LYONS K.M. 1969: Sense organs of monogenean skin parasites ending in a typical cilium. Parasitology 59: 611-623.

MALMBERG G. 1993: Gyrodactylidae and gyrodactylosis of salmonidae. Bull. Fr. Pêche Piscicult. 328: 5-46.

MAZZANTI C., MONNI G., VARRIALE A.M.C. 1999: Observations on antigenic activity of Pseudodactylogyrus anguillae (Monogenea) on the European eel (Anguilla anguilla). Bull. Eur. Assoc. Fish Pathol. 19: 57-59.

MO T.A. 1991: Seasonal variations of opisthaptoral hard parts of Gyrodactylus salaris Malmberg, 1957 (Monogenea: Gyrodactylidae) on parr of Atlantic salmon Salmo salar L. in laboratory experiments. Syst. Parasitol. 20: 11-20.
MO T.A. 1993: Seasonal variations of the opisthaptoral hard parts of Gyrodactylus derjavini Mikailov, 1975 (Monogenea: Gyrodactylidae) on brown trout Salmo trutta L. parr and Atlantic salmon Salmo salar L. parr in the River Sandvikselva, Norway. Syst. Parasitol. 26: 225-231.

MO T.A. 1997: Seasonal occurrence of Gyrodactylus derjavini (Monogenea) on brown trout, Salmo trutta, and Atlantic salmon, $S$. salar, in the Sandvikselva river, Norway. J. Parasitol. 83: 1025-1029.

RICHARDS G.R., CHUBB J.C. 1996: Host responses to initial and challenge infections, following treatment of Gyrodactylus bullatarudis and G. turnbulli (Monogenea) on the guppy (Poecilia reticulata). Parasitol. Res. 82: 242-247.

RUBIO-GODOY M., SIGH J., BUCHMANN K., TINSLEY R.C. 2003a: Immunization of rainbow trout Oncorhynchus mykiss against Discocotyle sagittata (Monogenea). Dis. Aquat. Org. 55: 23-30.

RUBIO-GODOY M., SIGH J., BUCHMANN K., TINSLEY R.C. 2003b: Antibodies against Discocotyle sagittata (Monogenea) in farmed trout. Dis. Aquat. Org. 56: 181-184.

SCOTT M.E., ROBINSON M.A. 1984: Challenge infections of Gyrodactylus bullatarudis (Monogenea) on guppies (Poecilia reticulata) following treatment. J. Fish Biol. 24: 581-586.

STERUD E., HARRIS P.H., BAKKE T.A. 1998: The influence of Gyrodactylus salaris Malmberg, 1957 (Monogenea) on the epidermis of Atlantic salmon, Salmo salar L., and brook trout, Salvelinus fontinalis (Mitchill): experimental studies. J. Fish Dis. 21: 257-263.

VLADIMIROV V.L. 1971: The immunity of fishes in the case of dactylogyrosis. Parazitologiya 5: 51-58. (In Russian.)

WANG G., KIM J.-H., SAMESHIMA M., OGAWA K. 1997: Detection of antibodies against the monogenean Heterobothrium okamotoi in Tiger puffer. Fish Pathol. 32: 179180.

WATSON N.A., ROHDE K. 1994: Two new sensory receptors in Gyrodactylus sp. (Platyhelminthes, Monogenea, Monopisthocotylea). Parasitol. Res. 80: 442-445.

WELLS P.R., CONE D.K. 1990: Experimental studies on the effect of Gyrodactylus colemanensis and G. salmonis on density of mucous cells in the epidermis of fry of Oncorhynchus mykiss. J. Fish Biol. 37: 599-603.

YOSHINAGA T., NAGAKURA T., OGAWA K., FUKUDA Y., WAKABAYASHI H. 2002: Attachment-inducing capacities of fish skin epithelial extracts on oncomiracidia of Benedenia seriolae (Monogenea: Capsalidae). Int. J. Parasitol. 32: 381-384.

YOSHINAGA T., NAGAKURA T., OGAWA K., WAKABAYASHI H. 2000: Attachment-inducing capacities of fish tissue extract on oncomiracidia of Neobenedenia girellae (Monogenea, Capsalidae). J. Parasitol. 86: 214 219.

Accepted 27 April 2004 